\title{
Retraction Note: Effect of Mixed-Phospholipid Layer on Phospholipase D Reaction-induced Vesicle Rupture
}

\author{
Jin-Won Park ${ }^{1}$
}

Published online: 21 June 2021

๑) Springer Science+Business Media, LLC, part of Springer Nature 2021

\section{Retraction to:}

The Journal of Membrane Biology (2012) 245:691-696

https://doi.org/10.1007/s00232-012-9438-2

The Editor-in-Chief has retracted this article because it shows significant overlap with a previously published article by the same author (Park 2012). The author does not agree to this retraction.

\section{Reference}

Park J-W (2012) Phase effect of mixed-phospholipid layer on phospholipase D reaction-induced-vesicle rupture. Colloids Surf B 97:207-210. https://doi.org/10.1016/j.colsurfb.2012.04.034

Publisher's Note Springer Nature remains neutral with regard to jurisdictional claims in published maps and institutional affiliations.
Jin-Won Park

jwpark@seoultech.ac.kr

1 Department of Chemical and Biomolecular Engineering,

College of Energy and Biotechnology, Seoul National

University of Science and Technology, 172 Gongreung

2-dong, Nowon-gu, Seoul 139-743, South Korea 